"Dynamic correlation analysis in the ASEAN equity markets during 2009-2018"

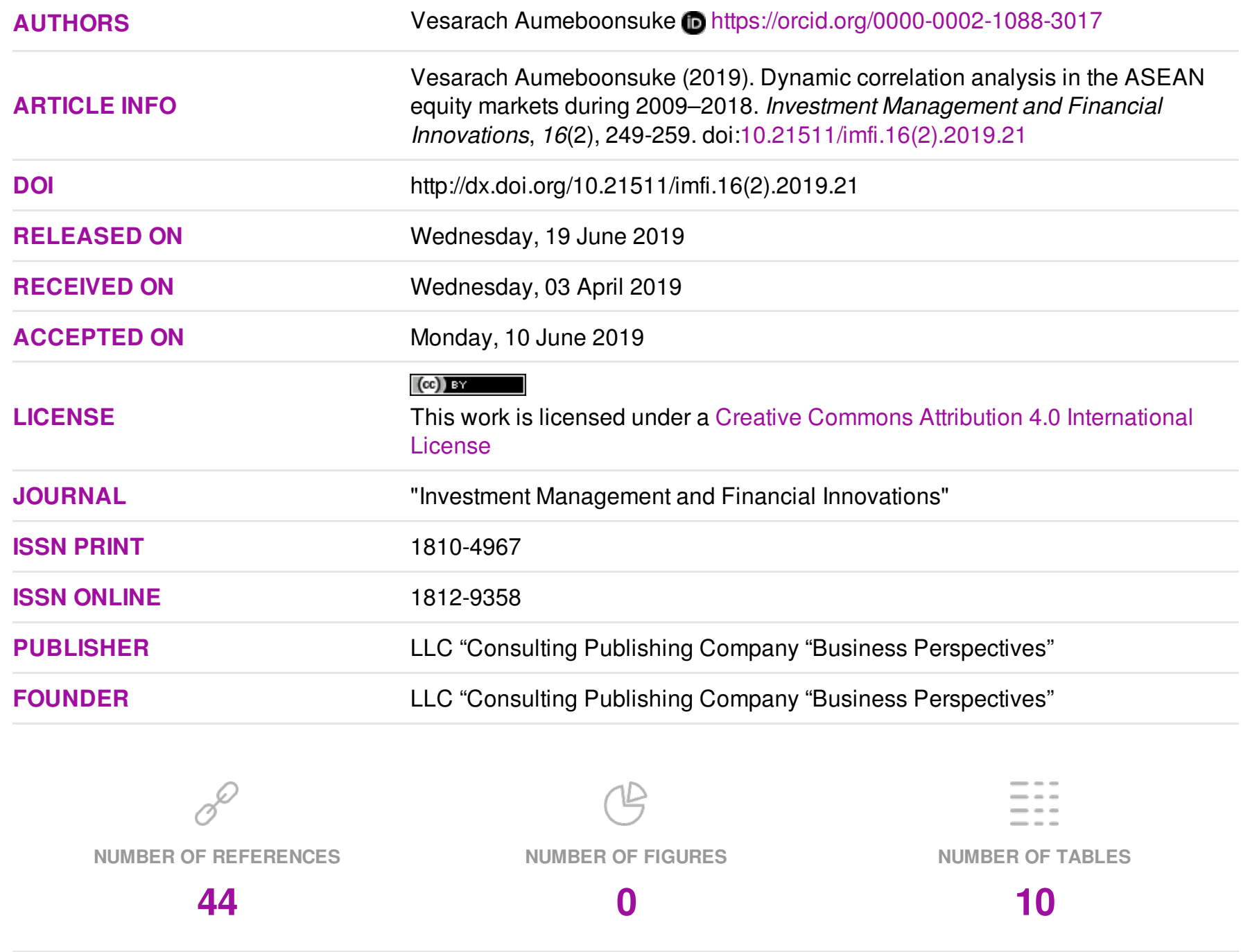

C The author(s) 2023. This publication is an open access article. 


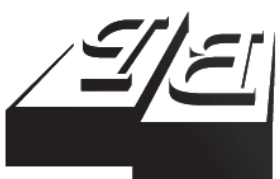

BUSINESS PERSPECTIVES

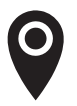

LLC "CPC "Business Perspectives" Hryhorii Skovoroda lane, 10, Sumy, 40022, Ukraine

www.businessperspectives.org

Received on: $3^{\text {rd }}$ of April, 2019 Accepted on: $10^{\text {th }}$ of June, 2019

(C) Vesarach Aumeboonsuke, 2019

Vesarach Aumeboonsuke, Ph.D., Associate Professor, Faculty of International College, International College, National Institute of Development Administration, Thailand.

\section{DYNAMIC CORRELATION ANALYSIS IN THE ASEAN EQUITY MARKETS DURING 2009-2018}

\begin{abstract}
This study examines the static and dynamic correlations in the ASEAN equity markets. The importance of this research appears from the fact that practitioners can get the benefit if their investments yield the same or higher returns given lower or the same risk in their portfolio. Firstly, this advantage comes from including the assets that decrease volatility of the portfolio. Hence, the correlation between the ASEAN markets should be examined. Secondly, co-movements in market realizations may increase global financial instability. Its existence is important for international investors, financial institutions, and policy makers. The study locates the relationship between ASEAN and its major trading partners, including Japanese, US, and UK markets, in order to find more rational results. This study utilizes alternative multivariate GARCH forms to provide useful information on the dynamic evolution and implications of return volatilities. The results show that the volatilities of all the equity markets under study are persistent over time. The estimates from VEC model indicate that the movements of the US and UK equity market returns have some degree of influence on several of the ASEAN equity markets. The results imply that, first, most of the developing ASEAN equity markets work by its own information with small relation to the developed world. Second, it is still convincing to state that investing in ASEAN equity markets should provide investors a better mean-variance portfolio. And, third, buy-and-hold strategy seems to be more beneficial than readjusting the ASEAN equities portfolio.
\end{abstract}

\section{Keywords}

equity markets, dynamic correlation, ASEAN, DCC-GARCH

\section{JEL Classification G11, G12, G15}

\section{INTRODUCTION}

In the past five years (2014-2018), growth in the ASEAN markets is anticipated to remain strong and relatively attractive for investment ${ }^{1}$. From the practitioner's point of view, these markets are always the significant investing places and the key investment targets for global diversified portfolio. Besides, one may suggest that equity price and volatility in one continent may be affected by the fluctuations in another continent beyond what is conceivable by associations through its economic fundamentals. In other words, changes in price and volatility are driven by an investment across borders. Hence, the risk of investors may not certainly decrease from only a naïve broad diversification. Although there have been several studies of correlation in price and volatility of major equity markets, there is a limited number of studies conducted for ASEAN markets. In addition, prior studies give us an idea that ASEAN markets are facing with many financial problems (e.g. market contagion and volatility spillover (see Cha \& Oh, 2000; Chiang et al., 2007; Bowman et al., 2010)), albeit ASEAN equity

1 Information from www.worldbank.org 
market can still give investors one way to construct an international well-diversified portfolio. In order to extend the knowledge and spot the root of these benefits, the study that is designed to investigate the correlations and their co-movements within ASEAN equity markets in details is substantially needed.

This study aims to examine the static and dynamic correlations in the ASEAN equity markets. The importance of this research appears from the fact that practitioners can get the benefit if their equity investments yield the same or higher returns given lower or the same risk in their overall portfolio. Firstly, this advantage comes from the assets that can decrease volatility of the portfolio. Hence, the correlation between the ASEAN markets needs to be examined. Secondly, co-movements in market realizations may raise the risk towards global financial instability. Its existence is also an important awareness for international investors, financial institutions, and policy makers.

This study is primarily motivated, because most research papers that investigate the return and volatility across international stock markets emphasized mainly on large markets in the United States, Europe, and Japan, with less consideration on the ASEAN markets. In addition, it can be extended to the issues such as volatility spillovers, correlation breakdowns, trends in correlation patterns, and financial crisis contagion. Therefore, the major beneficiaries are not only practitioners who attempt to find the best solution for their international asset allocation, but also scholars who involve in development of financial models that require correlation as an input.

This study is organized as follows. Section 1 reviews related literatures on these areas. Section 2 presents data and methodology that include descriptive statistics and relevant methodologies. Section 3 shows data analysis and evaluates the empirical findings. Final section concludes.

\section{REVIEWS OF THE LITERATURES}

The equity market correlations have been investigated in terms of returns and volatility for many decades. Among the many interesting elements, dynamic correlation and volatility trend earned the biggest attention. This is, perhaps, because we are using the model that assumes that investors select their portfolios based on the mean-variance criterion (Markowitz, 1959; Markowitz, 1991a; Markowitz, 1991b; Markowitz, Todd, \& Sharpe, 2000). Even though the model has been modified in various aspects, its basic form is still used, since it is an equilibrium model that offers a solid specification of the relationship between asset returns, and the empirical evidence proposes that it explains a significant fraction of the variation in asset returns (Markowitz et al., 2000). In present integrated world, one who wants to find the efficient portfolio must find internationally diversified portfolio, because it can dramatically enhance their risk-return performance, for example, low correlation between international markets can reduce the risk (Solnik, Boucrelle, \& Le Fur, 1996). In fact, this portfolio construction requires a full understanding in both return correlation and volatility relation.

Over the past two decades, there have been many developments to identify and quantify these dynamics of returns volatility and correlation across equity markets (e.g. Engle \& Ng, 1993; Koutmos \& Booth, 1995; Bekaert \& Wu, 2000). Among the best of them, generalized autoregressive conditional heteroscedasticity (GARCH) models are the most appealing, because they have recently added empirical evidences in modeling time-varying correlations and large covariance matrices (Bollerslev, Engle, \& Wooldridge, 1988; Engle, 1982). Many GARCH series that have outsized number of parameters and high degree of difficulty were developed in the past. Nevertheless, the simple model that suggests keeping constant correlations, Constant Conditional Correlation model (CCC), is still useful (Bollerslev, 1990).

In recent times, a new class of model, Dynamic Conditional Correlation (DCC), which allows the correlations to change over time, is also implemented (Engle, 2002). Still, the DCC is constrained to be equal for all the correlations. In fact, this is 
a pointless restriction and, thus, the flexibility of Asymmetric Dynamic Conditional Correlation (ADCC) that allows asymmetric effects in the variance functions might be a better option (Cappiello, Engle, \& Sheppard, 2006). From the researcher's point of view, all models have their own good characteristics. For example, comparing CCC and DCC can demonstrate the advantage of dynamic modeling, contrasting DCC and ADCC lights an idea of market asymmetry. Precisely, not only past, but also present research papers utilize the advantage from all models in modeling dynamic equity correlations and covariance criterion.

Nevertheless, empirical evidence discovers bad news that sometimes equity markets' correlations are changing over time and, therefore, it creates less diversification opportunities (Longin \& Solnik, 1995). After decades, the evidence shows that correlation between major equity markets remains high and even positive not only in terms of returns, but also volatility (Ang \& Chen, 2002; King, Sentana, \& Wadhwani, 1994; Longin \& Solnik, 1995, 2001; Morana \& Beltratti, 2002; Ramchand \& Susmel, 1998). Fortunately, this revolutionizing trend of correlation has been developing over time, even in present Morana and Beltratti (2008) and extending to be not in a straight line positive or negative side, but asymmetric when major equity markets are changing their trend (Koutmos \& Booth, 1995; Kroner \& Ng, 1998; Mazzotta, 2008; Yang \& Doong, 2004).

In addition, the existence of contagion between equity markets based on DCC-GARCH was found in several recent studies. Chittedi (2015) applied the DCC-GARCH model and reported the correlation between the US and Indian equity markets. Hou and Li (2016) also performed DCC-GARCH model and explored the information transmission between the US and Chinese markets. Furthermore, findings from Trabelsi (2017) showed that the Asian stock indexes can be considered as effective hedge assets. And most recently, Aawaar, Domeher, and Nsiah (2018) concluded that co-movements between stock markets in African and the world stock market are time-varying.

As a result, there are many researchers trying to find reason for the variation in the international transmission of stock returns and volatility.
According to Syriopoulos (2006), empirical literature has indicated a number of factors that may be responsible for equity market interrelationships, including economic policies, financial innovations, market deregulation, interest rate movements or financial crises with contagion effects. Because of the fact that world equity markets are sharing some economic fundamentals, many researchers examine equity return and volatility correlation from the financial crisis contagion effect between emerging and mature markets. That is, when we, unfortunately, realize that emerging equity markets, such as ASEAN markets, are now playing important roles to our well-diversified portfolios (Aggarwal, Inclan, \& Leal, 1999; Chaudhuri \& Wu, 2003; King \& Wadhwani, 1990; Syriopoulos, 2004; Yang, Kolari, \& Min, 2003).

Although the fact that international equity markets have stepped forward integration, the evidence still supports the existence of three regional groups, the North American, Europe, and ASEAN, rather than a particular world market (Engle \& Susmel, 1993; Groenen \& Franses, 2000). Regarding to empirical evidence of the relation between western and ASEAN markets, there is a support that the relationship between the developed markets and the ASEAN emerging markets is intense before and after the ASEAN financial crisis in July 1997 (Arshanapalli \& Doukas, 1993; Cha \& Oh, 2000; Cheung \& Ng, 1993; Liu \& Pan, 1997). In addition, an increase and continued in high correlation is statistically found in ASEAN daily stock-return data series from 1990 to 2003 (Chiang, Jeon, \& Li, 2007). Nevertheless, the benefits of international diversification in ASEAN equity markets are still substantially high (Bowman, Chan, \& Comer, 2010).

\section{DATA AND METHODOLOGY}

\subsection{Data and descriptive statistics}

As the study attempts to locate the relationship between ASEAN markets, the United States, East Asia market, and major European market, the daily index data from each relevant major exchange is collected from BLOOMBERG Database. The samples start from January 1, 2009 to January 1, 2019. 
Table 1. Stock market index descriptive statistics

\begin{tabular}{|c|c|c|c|c|c|c|c|c|c|}
\hline Log (level) & S\&P500 & FTSE100 & $\mathrm{JCl}$ & SET & FBMKLCI & PSE & VN & STI & N225 \\
\hline Mean & 7.05 & 8.54 & 6.92 & 6.31 & 6.81 & 7.56 & 5.80 & 7.65 & 8.77 \\
\hline Median & 7.06 & 8.56 & 7.00 & 6.49 & 6.80 & 7.56 & 5.69 & 7.63 & 8.84 \\
\hline Max & 7.36 & 8.82 & 8.02 & 6.82 & 7.32 & 8.26 & 7.07 & 8.25 & 9.21 \\
\hline Min & 6.52 & 8.10 & 5.82 & 5.52 & 6.32 & 6.89 & 4.61 & 7.07 & 7.65 \\
\hline Std. Dev. & 0.17 & 0.16 & 0.69 & 0.36 & 0.25 & 0.38 & 0.58 & 0.28 & 0.31 \\
\hline Skewness & -0.39 & -0.27 & -0.05 & -0.64 & 0.17 & 0.05 & 0.37 & 0.10 & -0.79 \\
\hline Kurtosis & 2.57 & 2.02 & 1.57 & 1.89 & 1.98 & 1.81 & 2.29 & 2.05 & 3.16 \\
\hline Jarque-Bera & 84.46 & 135.50 & 223.97 & 308.57 & 125.00 & 154.51 & 115.91 & 101.46 & 208.26 \\
\hline (prob.) & 0.00 & 0.00 & 0.00 & 0.00 & 0.00 & 0.00 & 0.00 & 0.00 & 0.00 \\
\hline ADF test & -2.02 & -2.07 & -2.32 & -1.61 & -2.49 & -2.10 & -1.63 & -2.00 & -1.72 \\
\hline (prob.) & 0.59 & 0.56 & 0.42 & 0.79 & 0.33 & 0.55 & 0.78 & 0.60 & 0.74 \\
\hline \multicolumn{10}{|l|}{ Return } \\
\hline Mean² & $-0.49 \%$ & $0.44 \%$ & $21.04 \%$ & $12.62 \%$ & $6.04 \%$ & $11.12 \%$ & $19.36 \%$ & $5.79 \%$ & $5.20 \%$ \\
\hline Median & $8.02 \%$ & $4.39 \%$ & $14.21 \%$ & $13.12 \%$ & $6.43 \%$ & $14.34 \%$ & $13.06 \%$ & $4.99 \%$ & $12.85 \%$ \\
\hline Maximum & $15.44 \%$ & $18.35 \%$ & $55.50 \%$ & $33.52 \%$ & $38.05 \%$ & $43.51 \%$ & $131.03 \%$ & $37.38 \%$ & $25.40 \%$ \\
\hline Minimum & $-31.50 \%$ & $-27.76 \%$ & $-10.21 \%$ & $-20.71 \%$ & $-19.30 \%$ & $-30.22 \%$ & $-74.19 \%$ & $-24.66 \%$ & $-29.43 \%$ \\
\hline Std. Dev. & 0.01 & 0.01 & 0.01 & 0.01 & 0.01 & 0.01 & 0.02 & 0.01 & 0.02 \\
\hline Skewness & 0.11 & 0.04 & -0.48 & -0.52 & -0.82 & 1.02 & -0.13 & -0.03 & 0.16 \\
\hline Kurtosis & 11.49 & 9.73 & 9.09 & 12.32 & 12.51 & 24.04 & 5.58 & 7.22 & 15.12 \\
\hline Jarque-Bera & 7836.65 & 4920.83 & 4125.29 & 9554.94 & 10099.79 & 48495.06 & 727.31 & 1930.36 & 12086.74 \\
\hline Probability & 0.00 & 0.00 & 0.00 & 0.00 & 0.00 & 0.00 & 0.00 & 0.00 & 0.00 \\
\hline ADF test & -40.85 & -24.97 & -45.25 & -33.40 & -43.56 & -45.25 & -20.88 & -50.24 & -49.46 \\
\hline (prob.) & 0.00 & 0.00 & 0.00 & 0.00 & 0.00 & 0.00 & 0.00 & 0.00 & 0.00 \\
\hline Observations & 2605 & 2605 & 2605 & 2605 & 2605 & 2605 & 2605 & 2605 & 2605 \\
\hline
\end{tabular}

Note: All estimates are based on data for the period from January 1, 2009 to January 1, 2019.

The data of western equity market includes, first, US Standard and Poor's capitalization-weighted index of 500 large-cap stocks traded on either the NYSE or NASDAQ (S\&P500). Second, UK capitalization-weighted index of the 100 most highly capitalized companies, Financial Times Stock Exchange, traded on the London Stock Exchange (FTSE100). Third, Japanese's Nikkei 225 calculated by the Nikkei Keizai newspaper, Nikkei 225 is a price-weighted average of 225 top-rated Japanese companies listed in the First Section of the Tokyo Stock Exchange (N225). For ASEAN market, the data contain, first, Indonesian Jakarta Composite Index, a capitalization-weighted index of stocks traded on the board of the Indonesia Stock Exchange (JCI). Second, Stock Exchange of Thailand's capitalization-weighted index of stocks listed on the Stock Exchange of Thailand (SET). Third, FTSE Bursa Malaysia Kuala Lumpur Composite Index, the largest 30 companies weighted by full market capitalization on Bursa Malaysia's Main Board (FBMKLCI). Forth, Philippine Stock Exchange's capitalization-weighted index composed of stocks representative of the Services, Industrial, Holding
Firms, Properties, Financial and Mining \& Oil Sectors of the Philippine Stock Exchange (PSE). Fifth, Vietnam's capitalization-weighted index of all the companies listed on the Ho Chi Minh Stock Exchange, Vietnam (VN). And sixth, Straits Times Index, a market value-weighted index calculated and disseminated by FTSE, comprises the top 30 stocks listed on the Singapore Exchange (STI).

At a starting point, the descriptive statistics and relevant tests are conducted on the equity market index and market returns. Table 1 summarizes descriptive statistics of the equity indices from the following markets: JCI: Indonesia; SET: Thailand; FBMKLCI: Malaysia; PSE: Philippines; VN: Vietnam; STI: Singapore; N225: Japan. Statistics include mean, median, maximum, minimum, standard deviation, skewness, kurtosis, JarqueBera normality test, and Augmented DickeyFuller (ADF) unit root test. For each equity market index, the descriptive statistics are computed at both natural logarithms and return values. The data frequency is daily. The data covers the period from January 1, 2009 to January 1, 2019.

2 Mean, Median, Maximum, and Minimum of Return are statistics from annual basis. 
Table 2. Unconditional correlation matrix of market return

\begin{tabular}{|c|c|c|c|c|c|c|c|c|c|c|}
\hline & S\&P 500 & FTSE 100 & SSE & $\mathrm{JCl}$ & SET & FBMKLCI & PSE & VN & STI & N225 \\
\hline S\&P500 & 1 & - & - & - & - & - & - & - & - & - \\
\hline FTSE100 & 0.5146 & 1 & - & - & - & - & - & - & - & - \\
\hline SSE & 0.0351 & 0.0905 & 1 & - & - & - & - & - & - & - \\
\hline $\mathrm{JCl}$ & 0.0948 & 0.2492 & 0.1776 & 1 & - & - & - & - & - & - \\
\hline SET & 0.1625 & 0.2682 & 0.1583 & 0.4025 & 1 & - & - & - & - & - \\
\hline $\mathrm{FBMKLCl}$ & 0.0656 & 0.2063 & 0.1917 & 0.408 & 0.3777 & 1 & - & - & - & - \\
\hline PSE & 0.0114 & 0.1365 & 0.1351 & 0.3344 & 0.2544 & 0.3336 & 1 & - & - & - \\
\hline VN & -0.0191 & 0.0349 & 0.0614 & 0.0795 & 0.065 & 0.0692 & 0.1368 & 1 & - & - \\
\hline STI & 0.2357 & 0.4028 & 0.2205 & 0.4977 & 0.4713 & 0.4798 & 0.2935 & 0.0588 & 1 & - \\
\hline N225 & 0.9197 & 0.5262 & 0.0387 & 0.1383 & 0.1843 & 0.1208 & 0.0317 & -0.0075 & 0.2613 & 1 \\
\hline
\end{tabular}

Note: All estimates are based on data for the period from January 1, 2009 to January 1, 2019.

Table 2 shows unconditional correlation matrix of market return. The coefficients for unconditional correlation in the returns of equity index indicate strong correlations among the western equity markets and Japan equity market ( 0.9197 for US's S\&P500 and Japanese's Nikkei 225). Moreover, the evidence here shows weak correlations among western equity markets and ASEAN equity markets (except those of Japan). This initial exploration of (static) correlation, coefficients show that the western equity markets do not affect the ASEAN equity markets substantially.

\section{METHODOLOGY}

To produce information on the dynamic progression of the return volatilities, the method of this study utilizes three alternative multivariate GARCH forms, namely Constant Conditional Correlation (CCC) model (Bollerslev, 1990), and Dynamic Condition Correlation (DCC) model (Engle, 2002). The CCC is the two-stage estimator of conditional variances and correlations. In the first stage, a univariate GARCH model is estimated, and then the univariate variance estimates from the first stage GARCH model are the inputs in the second stage of the estimation process. The DCC is similar to the CCC in the sense that they are both two-stage estimators of conditional variances and correlations. Unlike the CCC model, which retains the conditional correlation constant, the DCC model captures the dynamics of time-varying conditional correlations by specifying the covariance matrix $H_{t}$ as follows:

$$
H_{t}=D_{t} R_{t} D_{t} \text {, }
$$

where $D_{t}=\operatorname{diag}\left\{\sqrt{h_{i, t}}\right\}$ denotes $n \times n$ diagonal matrix that shows the squared root of each conditional variance in the diagonal and $R_{t}=\left\{\rho_{i, j}\right\}_{t}$

denotes the time-varying conditional correlations matrix. The DCC model allows $R_{t}$ to vary in time (unlike the CCC model that does not). The first order univariate GARCH process is as follows:

$$
h_{i, t}=\omega_{i}+\alpha \varepsilon_{i, t-1}^{2}+\beta h_{i, t-1},
$$

where $i$ are $1,2, \ldots, m$, indicating the $i$ equation in the Vector Error Correction (VEC) model derived from the initial stage of the estimation process, $\varepsilon_{i, t}$ are the error terms of the $i$ equation in the VEC model, $h_{i, t}$ are the conditional variances of the error terms.

The second stage of the estimation uses the vector of the standardized residuals to develop the DCC correlation specification:

$Q_{t}=\left(1-\theta_{1}-\theta_{2}\right) \bar{Q}+\theta_{1} \eta_{t-1} \eta_{t-1}^{\prime}+\theta_{2} Q_{t-1}$,

and

$$
R_{t}=Q_{t}^{*-1} Q_{t} Q_{t}^{*-1},
$$

where $Q_{t}$ is the covariance matrix of $\eta_{t}, \theta_{1}, \theta_{2}$ are scalar parameters capturing the effects of previous shocks and previous dynamic conditional correlations on current dynamic conditional correlations, $\eta_{t}=D_{t}^{-1} \varepsilon_{t}$ is the standardized residual matrix, $\bar{Q}=E\left[\eta_{t} \eta_{t}^{\prime}\right]$ is the unconditional covariance of the standardized residuals $\left(\eta_{t}\right)$ and

$$
Q_{t}^{*}=\left(\operatorname{diag}\left(Q_{t}\right)\right)^{-\frac{1}{2}}=\operatorname{diag}\left(\frac{1}{\sqrt{q_{11, t}}}, \ldots, \ldots, \frac{1}{\sqrt{q_{m m, t}}}\right)
$$


is a diagonal matrix composed of the square root of the diagonal elements of $Q_{t}$.

Initially, the matrix $\bar{Q}$ is computed. At this process, the correlations of the unconditional sample are used to estimate the long-run correlations. Then, in the next stage, matrix $\bar{Q}$ is substituted by $T^{-1} \sum \eta_{t} \eta_{t}^{\prime}$ in order to estimate parameters $\theta_{1}$ and $\theta_{2} t=1$ The DCC model is estimated using the maximum log-likelihood method.

In the $\operatorname{DCC}(1,1)$ case, the parameters $\theta_{1}$ and $\theta_{2}$ are positive and $\theta_{1}+\theta_{2}<1$, so $Q_{t}$ is positive and mean-reverting. This suggests that after a shock does happens, the correlation between the series will convert to the long-run unconditional level. When $\theta_{1}=\theta_{2}=0$, the DCC model is reduced to the CCC model. From Matrix $Q_{t}$ and equation (4), the correlation estimators are as follows:

$\rho_{i, j, t}=\frac{q_{i j, t}}{\sqrt{q_{i i, t} q_{j j, t}}}$ for $i, j=1,2, \ldots, n$ and $i \neq j$.

The study plans to estimate the equity markets' correlation values from CCC and DCC models, and then compare the results and report the findings.

\section{EMPIRICAL RESULTS}

\subsection{Johansen's test statistics for cointegration rank}

First, the mean specifications of the underlying series are investigated, followed by the approximation of the constant and dynamic conditional correlations of the equity markets under this study. This procedure is performed following the work of Syriopoulos and Roumpis (2009). The test for the existence of any cointegrating vector is used in order to identify any possible linkage and association among the equity markets under this study. According to the $\lambda_{\text {trace }}$ and $\lambda_{\text {max }}$ tests in Table 3 , based on both tests, the null hypothesis that the eastern, southeastern ASEAN markets, and the United States plus major European markets are not cointegrated is rejected.
Table 3. Johansen's test statistics for cointegration rank ${ }^{3}$

\begin{tabular}{|c|c|c|c|}
\hline Null & \multirow[b]{2}{*}{ Eigenvalues } & \multirow[b]{2}{*}{$\lambda_{\text {trace }}$ test } & \multirow{2}{*}{$\begin{array}{c}\text { Critical } \\
\text { values at } \\
95 \%\end{array}$} \\
\hline $\begin{array}{c}\text { Model } \\
\text { specification }\end{array}$ & & & \\
\hline$r=0$ & 0.2741772 & 4962.6492 & 334.98371 \\
\hline$r \leq 1$ & 0.2566371 & 4332.3254 & 285.14251 \\
\hline$r \leq 2$ & 0.2234933 & 3748.9704 & 239.23541 \\
\hline$r \leq 3$ & 0.2171877 & 3251.4177 & 197.37087 \\
\hline$r \leq 4$ & 0.206169 & 2769.7735 & 159.5297 \\
\hline$r \leq 5$ & 0.1825447 & 2315.6234 & 125.61543 \\
\hline$r \leq 6$ & 0.1730716 & 1919.1568 & 95.753661 \\
\hline$r \leq 7$ & 0.1667267 & 1545.3536 & 69.818887 \\
\hline$r \leq 8$ & 0.1595673 & 1186.5853 & 47.856127 \\
\hline$r \leq 9$ & 0.1514807 & 844.64512 & 29.797073 \\
\hline$r \leq 10$ & 0.1371456 & 521.54092 & 15.494713 \\
\hline$r \leq 11$ & 0.1109804 & 231.39002 & 3.8414655 \\
\hline Null & \multirow[b]{2}{*}{$\lambda_{\text {trace }}$ test } & \multirow[b]{2}{*}{$\begin{array}{c}\text { Critical } \\
\text { values at } \\
95 \%\end{array}$} & \multirow[b]{2}{*}{-} \\
\hline $\begin{array}{l}\text { Tests for the } \\
\text { number of } \\
\text { cointegration } \\
\text { vectors }\end{array}$ & & & \\
\hline$r=0$ & 630.3238 & 76.57843 & - \\
\hline$r=1$ & 583.355 & 70.535134 & - \\
\hline$r=2$ & 497.55279 & 64.504717 & - \\
\hline$r=3$ & 481.64415 & 58.433538 & - \\
\hline$r=4$ & 454.15014 & 52.36261 & - \\
\hline$r=5$ & 396.46658 & 46.23142 & - \\
\hline$r=6$ & 373.80317 & 40.077574 & - \\
\hline$r=7$ & 358.7683 & 33.876867 & - \\
\hline$r=8$ & 341.9402 & 27.584338 & - \\
\hline$r=9$ & 323.10421 & 21.131616 & - \\
\hline
\end{tabular}

Note: All estimates are based on data for the period from January 1, 2009 to January 1, 2019.

The empirical evidence based on the VEC model (with up to two-lags) are summarized in Table 4. The error correction term (ECT) is found to be statistically significant for all of the sample equity markets, implying that short-run dynamics ensure reversion back to the common trend. The effects of the US and UK equity markets on most of the ASEAN equity markets are discovered. The causal relationships among the equity markets under study are illustrated by the lagged terms that are statistically significant. The lagged cross-market returns' joint significance shows that the US and UK equity market returns influenced some of the ASEAN equity market returns.

Subsequently, researcher estimates a univariate GARCH $(1,1)$ model, which is the most suitable GARCH model based on the Akaike and Schwarz criteria, in order to produce the standardized residuals, which would be the inputs to the con-

3 The process is conducted to investigate the existence of cointegration across equity market. The number of cointegrating vectors is denoted by $\mathrm{r}$ and is determined by two tests statistics: the "trace test" and the "maximum eigenvalue test" to test for the hypothesis of the existence of $\mathrm{r}$ cointegrating vectors (if $\mathrm{r}=0$, then no cointegration vector is present) (Johansen, 1991; Osterwald-Lenum, 1992). 
stant and dynamic conditional correlation models. Table 5 shows the results from GARCH $(1,1)$. Except for the Singaporean Straits Times Index, $\alpha$ and $\beta$ coefficients (ARCH and GARCH effects, respectively) for all the equity markets were positive and statistically significant at 5\% level. This result implies that the variance of the current error term (or innovation) is a function of the previous error terms, and that there is persistency in the variance of the equity markets.

\subsection{The conditional correlation model}

Based on the standardized residuals of the univariate $\operatorname{GARCH}(1,1)$, researcher performs the CCC and DCC models in order to further examine constant and dynamic conditional correlations in the equity markets. Table 6 shows the estimation results for CCC model. It is crucial to note that they all seem to be, on average, less than the respective unconditional correlations. CCC model summarizes correlation range from the lowest of 0.00142 (Japan-Vietnam) to the highest of 0.92988 (JapanU.S.) From ASEAN-ASEAN correlation perspective, the highest CCC correlation is Hong Kong and Singapore (0.66736), while Vietnam seems to be the least correlated with all other ASEAN markets. Thus, even though all the constant correlations are positive, most of their magnitudes seem too small to give us clear illustration on the co-movements in ASEAN equity markets.

Consequently, researcher further investigates DCC model to gain more understanding. Table 7 to Table 10 show the descriptive results of DCC model in terms of mean, max, min and standard deviation of the correlations between each pair of equity markets. A perusal of DCC estimates reveals noticeable similarities to CCC for all equity markets pairs. Japan-U.S. (0.9296) still has the highest correlation among our sample. Moreover, Singaporean Straits Times Index seems to have the highest correlation with each of the other ASEAN markets, with the highest of 0.5205 (SingaporeIndonesia) and the lowest of 0.0564 (SingaporeVietnam). On the contrary, Vietnamese Ho Chi Minh Stock Exchange seems to have the lowest correlation with each of the other ASEAN markets, with the highest of 0.1297 (Vietnam-Philippines) and the lowest of 0.0290 (Vietnam-Thailand).

Table 4. Vector error corrections model estimates and analysis

\begin{tabular}{|c|c|c|c|c|c|c|c|c|c|c|}
\hline Laggec & $\mathrm{D}(\mathrm{JCl})$ & $\mathrm{D}(\mathrm{KL})$ & & & $\mathrm{D}$ (PCOM) & $\mathrm{D}(\mathrm{SET})$ & $\mathrm{D}(\mathrm{SPX})$ & $\mathrm{D}(\mathrm{STI})$ & $\mathrm{D}(\mathrm{UKX})$ & $D(V N)$ \\
\hline ECT & $-0.14075^{* *}$ & $-0.04393^{* *}$ & $-0.12699 * *$ & $0.12915^{* *}$ & $-0.03542 * *$ & $-0.12747 * *$ & $0.07763^{* *}$ & $-0.20134^{* *}$ & $-0.1667^{* *}$ & $0.0142 *$ \\
\hline & & $0.06836 * *$ & $0.08464 * *$ & $0.056 *$ & $10343 * *$ & $0.05406 * *$ & 0.03171 & $0.0536^{* *}$ & $0.03505^{*}$ & -0.00818 \\
\hline & & $0.04132 * *$ & $0.04968^{*}$ & $0.08065^{* *}$ & $0.06785^{* *}$ & $0.05938 * *$ & $0.05801^{* *}$ & 0.03413 & $0.0691^{* *}$ & \\
\hline & & & & & 03076 & -0.06025 & -0.02313 & & $-0.11177^{* *}$ & \\
\hline & & & & & & & & & & \\
\hline & & & & & & & & & & \\
\hline & & & & & & & & & & \\
\hline & & & & & & & & & & \\
\hline & & & & & & & & & & \\
\hline & & & & & & & & & & \\
\hline & & & & & & & & & & \\
\hline & & & & & & & & & & \\
\hline & & & & & & & & & & \\
\hline & & & & & & & & & & \\
\hline & & & & & & & & & & \\
\hline & & & & & & & & & & \\
\hline & & & & & & & & & & \\
\hline & & & & & & $* *$ & -0 & & & \\
\hline & & & $2 * *$ & -0.178 & 0.1334 & $0.17198^{* *}$ & -0.7 & 0.29 & & $21^{*}$ \\
\hline & & & & & & & & & & \\
\hline & & & & & & & -0. & & & \\
\hline$C$ & & & & & & & & & & \\
\hline & & & & & & & & & & \\
\hline Adj. & 35590 & & & 0.43497 & 0.44866 & 0.42216 & 0.45366 & 0.49814 & 0.49685 & \\
\hline Log & 5363. & 6602.9 & 5372.17591 & 4690. & 5703.24949 & 5425 & 5506.28178 & 5781.93908 & 5729.27082 & 25202 \\
\hline & & & & & & & & & & \\
\hline schwarz SC & -5.34829 & -6.60676 & -5.35659 & -4.66389 & -5.69288 & -5.41113 & -5.49281 & -5.77281 & -5.71931 & -5.18464 \\
\hline
\end{tabular}

Note: All estimates are based on data for the period from January 1, 2009 to January 1, 2019. 
Table 5. Univariate generalized autoregressive conditional heteroskedasticity (GARCH $(1,1))$ estimates

\begin{tabular}{l|c|c|c|c}
\hline \multicolumn{1}{c}{ Index } & $\omega$ & $\alpha$ & $\beta$ & $\alpha+\beta$ \\
\hline S\&P500 & $0.00000(0.0000)$ & $0.10481(0.00822)$ & $0.88547(0.00898)$ & 0.99028 \\
FTSE100 & $0.00000(0.0000)$ & $0.12015(0.01076)$ & $0.87729(0.01043)$ & 0.99743 \\
JCI & $0.00001(0.0000)$ & $0.11505(0.00837)$ & $0.84419(0.00702)$ & 0.95923 \\
SET & $0.00002(0.0000)$ & $0.08453(0.01046)$ & $0.83662(0.01515)$ & 0.92115 \\
FBMKLCI & $0.00000(0.0000)$ & $0.14825(0.00878)$ & $0.83004(0.01101)$ & 0.97828 \\
PSE & $0.00001(0.0000)$ & $0.1016(0.00858)$ & $0.85918(0.01034)$ & 0.96078 \\
VN & $0.00001(0.0000)$ & $0.23653(0.01682)$ & $0.75809(0.01034)$ & 0.99462 \\
STI & $0.00000(0.0000)$ & $0.1062(0.01044)$ & $0.88813(0.00996)$ & 0.99433 \\
N225 & $0.00000(0.0000)$ & $0.08948(0.00845)$ & $0.91052(0.01018)$ & 1.00000 \\
\hline
\end{tabular}

Note: The table summarizes the estimated coefficients produced by the univariate $\operatorname{GARCH}(1,1)$ model. The coefficient $\omega$ is the constant term, $\alpha$ and $\beta$ are the ARCH and GARCH terms, respectively, in the conditional variance equations. The value of $\alpha+\beta$ reflects the volatility persistence. Numbers in parenthesizes denotes the $p$-values. All estimates are based on data for the period from January 1, 2009 to January 1, 2019.

Table 6. Conditional correlation generalized autoregressive conditional heteroskedasticity (CCC-GARCH(1,1)) estimates

\begin{tabular}{|c|c|c|c|c|c|c|c|c|c|}
\hline Index & S\&P500 & FTSE100 & $\mathrm{JCl}$ & SET & FBMKLCI & PSE & VN & STI & N225 \\
\hline S\&P500 & 1 & - & - & - & - & - & - & - & - \\
\hline FTSE100 & 0.50714 & 1 & - & - & - & - & - & - & - \\
\hline $\mathrm{JCl}$ & 0.08416 & 0.27377 & 1 & - & - & - & - & - & - \\
\hline SET & 0.10261 & 0.26976 & 0.41073 & 1 & - & - & - & - & - \\
\hline $\mathrm{FBMKLCl}$ & 0.06208 & 0.22543 & 0.44334 & 0.3731 & 1 & - & - & - & - \\
\hline PSE & 0.0169 & 0.12771 & 0.34409 & 0.26381 & 0.35846 & 1 & - & - & - \\
\hline $\mathrm{VN}$ & 0.00146 & 0.03979 & 0.07093 & 0.02905 & 0.07301 & 0.1297 & 1 & - & - \\
\hline STI & 0.17418 & 0.38916 & 0.52058 & 0.44206 & 0.48194 & 0.31703 & 0.05638 & 1 & - \\
\hline N225 & 0.92988 & 0.51506 & 0.10738 & 0.11291 & 0.08966 & 0.03511 & 0.00142 & 0.20681 & 1 \\
\hline
\end{tabular}

Note: All estimates are based on data for the period from January 1, 2009 to January 1, 2019.

Table 7. Dynamic correlation generalized autoregressive conditional heteroskedasticity (DCC-GARCH(1,1)) estimates (mean of correlations)

\begin{tabular}{c|c|c|c|c|c|c|c|c|c}
\hline \multicolumn{1}{c}{ Index } & S\&P500 & FTSE100 & SSE & SET & FBMKLCI & PSE & VN & STI & N225 \\
\hline S\&P500 & 1 & - & - & - & - & - & - & - & - \\
FTSE100 & 0.5070344 & 1 & - & - & - & - & - & - & - \\
JCI & 0.0841431 & 0.273729 & 0.2001792 & - & - & - & - & - & - \\
SET & 0.1025947 & 0.2697193 & 0.165462 & 1 & - & - & - & - & - \\
FBMKLCI & 0.062072 & 0.2254115 & 0.2267923 & 0.3730801 & 1 & - & - & - & - \\
PSE & 0.0168938 & 0.1276897 & 0.1376336 & 0.2637857 & 0.3584426 & 1 & - & - & - \\
VN & 0.0014635 & 0.039787 & 0.0383679 & 0.0290474 & 0.0730056 & 0.129688 & 1 & - & - \\
STI & 0.1741553 & 0.3891157 & 0.2193993 & 0.4420237 & 0.4819206 & 0.3170067 & 0.0563762 & 1 & - \\
N225 & 0.9295826 & 0.5149104 & 0.048224 & 0.1128874 & 0.0896474 & 0.0350998 & 0.0014269 & 0.2067717 & 1 \\
\hline
\end{tabular}

Note: All estimates are based on data for the period from January 1, 2009 to January 1, 2019.

Table 8. Dynamic correlation generalized autoregressive conditional heteroskedasticity (DCC-GARCH(1,1)) estimates (maximum of correlations)

\begin{tabular}{|c|c|c|c|c|c|c|c|c|c|}
\hline Index & S\&P500 & FTSE100 & $\mathrm{JCl}$ & SET & FBMKLCI & PSE & VN & STI & N225 \\
\hline S\&P500 & 1 & - & - & - & - & - & - & - & - \\
\hline FTSE100 & 0.50713 & 1 & - & - & - & - & - & - & - \\
\hline $\mathrm{JCl}$ & 0.0841573 & 0.2737621 & 1 & - & - & - & - & - & - \\
\hline SET & 0.1026077 & 0.2697527 & 0.4107158 & 1 & - & - & - & - & - \\
\hline FBMKLCl & 0.0620799 & 0.2254262 & 0.4433308 & 0.3730925 & 1 & - & - & - & - \\
\hline PSE & 0.016907 & 0.1277067 & 0.3440792 & 0.263802 & 0.3584534 & 1 & - & - & - \\
\hline VN & 0.0015026 & 0.039801 & 0.0709349 & 0.0291213 & 0.0730131 & 0.1296947 & 1 & - & - \\
\hline STI & 0.1741764 & 0.3891524 & 0.5205661 & 0.4420486 & 0.4819326 & 0.3170226 & 0.0563934 & 1 & - \\
\hline N225 & 0.9298566 & 0.5150474 & 0.107376 & 0.1129058 & 0.0896597 & 0.0351158 & 0.0015034 & 0.2068055 & 1 \\
\hline
\end{tabular}

Note: All estimates are based on data for the period from January 1, 2009 to January 1, 2019. 
Table 9. Dynamic correlation generalized autoregressive conditional heteroskedasticity (DCC$\operatorname{GARCH}(1,1)$ ) estimates (minimum of correlations)

\begin{tabular}{|c|c|c|c|c|c|c|c|c|c|}
\hline Index & S\&P500 & FTSE100 & $\mathrm{JCl}$ & SET & FBMKLCl & PSE & VN & STI & N225 \\
\hline S\&P500 & 1 & - & -- & - & - & - & - & - & - \\
\hline FTSE100 & 0.5056139 & 1 & - & - & - & - & - & - & - \\
\hline $\mathrm{JCl}$ & 0.0838012 & 0.2730053 & 1 & - & - & - & - & - & - \\
\hline SET & 0.1021718 & 0.2689207 & 0.4097395 & 1 & - & - & - & - & - \\
\hline FBMKLCI & 0.0619627 & 0.2250284 & 0.4427536 & 0.372634 & 1 & - & - & - & - \\
\hline PSE & 0.0167619 & 0.1271944 & 0.3432809 & 0.2629655 & 0.3580265 & 1 & - & - & - \\
\hline VN & 0.0014243 & 0.0396341 & 0.0706744 & 0.0288067 & 0.0728628 & 0.1292156 & 1 & - & - \\
\hline STI & 0.1736081 & 0.3880434 & 0.5193968 & 0.441103 & 0.4813474 & 0.3162407 & 0.0561941 & 1 & - \\
\hline N225 & 0.9264119 & 0.513231 & 0.1068757 & 0.1124081 & 0.0894926 & 0.0348604 & 0.0013418 & 0.2060924 & 1 \\
\hline
\end{tabular}

Note: All estimates are based on data for the period from January 1, 2009 to January 1, 2019.

Table 10. Dynamic correlation generalized autoregressive conditional heteroskedasticity (DCCGARCH(1,1)) estimates (standard deviation of correlations)

\begin{tabular}{|c|c|c|c|c|c|c|c|c|c|}
\hline Index & S\&P500 & FTSE100 & $\mathrm{JCl}$ & SET & FBMKLCI & PSE & VN & STI & N225 \\
\hline S\&P500 & - & - & - & - & - & - & - & - & - \\
\hline FTSE100 & 0.01571 & - & - & - & - & - & - & - & - \\
\hline $\mathrm{JCl}$ & 0.00376 & 0.00821 & - & - & - & - & - & - & - \\
\hline SET & 0.00395 & 0.00724 & 0.00829 & - & - & - & - & - & - \\
\hline FBMKLCI & 0.00132 & 0.00384 & 0.00587 & 0.00394 & - & - & - & - & - \\
\hline PSE & 0.00116 & 0.00487 & 0.00724 & 0.00579 & 0.00455 & - & - & - & - \\
\hline VN & 0.00083 & 0.00161 & 0.00259 & 0.00202 & 0.00146 & 0.00379 & - & - & - \\
\hline STI & 0.00604 & 0.01158 & 0.0122 & 0.00909 & 0.00622 & 0.00722 & 0.00196 & - & - \\
\hline N225 & 0.04639 & 0.02281 & 0.00607 & 0.00544 & 0.00243 & 0.00223 & 0.00134 & 0.00985 & - \\
\hline
\end{tabular}

Note: All estimates are based on data for the period from January 1, 2009 to January 1, 2019.

\section{CONCLUDING REMARKS}

When forming the portfolio, the correlations between equity markets are always an essential factor for all investors. This study explores the correlations among nine equity markets, which are East Asia, ASEAN, and major western equity markets, including the United States, England, Japan, Indonesia, Thailand, Malaysia, Philippine, Vietnam, and Singapore.

This study finds small differences in correlations between univariate, CCC-GARCH, and DCC-GARCH models. The estimates from VEC model indicate that the movements of the US and UK equity market returns have some degree of influence on several of the ASEAN equity markets. By comparing the estimates from CCC and DCC, it can be concluded that the correlations of equity markets are not dramatically changing along the time. From these results, researcher can draw three implications as follows:

1. Most of the developing ASEAN equity markets work by its own information with small relation to the developed world (for example, there is high correlation between equity market of Japan and the US, but low correlation between these developed markets and the ASEAN countries).

2. It is still convincing to state that investing in ASEAN equity markets should provide investors a better mean-variance portfolio, because some pairs of ASEAN equity markets are weakly correlated. Nevertheless, the descriptive statistics of the ASEAN equity markets returns show not much difference in volatility, but noticeable difference in mean. This evidence suggests us to invest only in performed market. 
3. Readjusting the ASEAN equities portfolio may be less beneficial, since the results show little difference between constant and dynamic correlations models.

The results from this study contribute additional evidence to the study of co-movements among equity markets. Although previous studies on the US and Indian markets (Chittedi, 2015), and the US and Chinese markets (Hou \& Li, 2016) found that co-movements exist, this study shows that co-movements exist among the US, UK, and Japan equity markets, but not for the ASEAN equity markets.

Future additional empirical research on these findings would be to explore how the economic cycle would cause the ASEAN equity markets to have higher (or lower) correlations among themselves and with the other non-ASEAN equity markets. Besides, it may be interesting to examine whether the degree of the movements in correlations will have the same magnitude when the markets experience bull and bear periods. Finally, further research may also investigate the reasons to explain why the ASEAN equity markets are so independent of one another.

\section{REFERENCES}

1. Aawaar, G., Domeher, D., \& Nsiah, C. (2018). Evolving Co-Movements of Africa's Stock Markets: Evidence from DCC-GARCH Analysis. International Research Journal of Finance and Economics, 170, 110131. Retrieved from http://www. internationalresearchjournaloffinanceandeconomics.com/ISSUES/ IRJFE_170_09.pdf

2. Aggarwal, R., Inclan, C., \& Leal, R. (1999). Volatility in Emerging Stock Markets. The Journal of Financial and Quantitative Analysis, 34(1), 3355. https://doi.org/10.2307/2676245

3. Ang, A., \& Chen, J. (2002). Asymmetric correlations of equity portfolios. Journal of Financial Economics, 63(3), 443-494. https://doi.org/10.1016/S0304405X(02)00068-5

4. Arshanapalli, B., \& Doukas, J. (1993). International stock market linkages: Evidence from the pre-and postOctober 1987 period. Journal of Banking \& Finance, 17(1), 193-208. https://doi.org/10.1016/03784266(93)90088-U

5. Bekaert, G., \& Wu, G. (2000). Asymmetric volatility and risk in equity markets. Review of Financial Studies, 13(1), 1-42. Retrieved from https://www.nber.org/papers/w6022

6. Bollerslev, T. (1990). Modelling the coherence in short-run nominal exchange rates: a multivariate generalized ARCH model. The Review of Economics and Statistics,
72(3), 498-505. https://doi. org/10.2307/2109358

7. Bollerslev, T., Engle, R. F., \& Wooldridge, J. M. (1988). A Capital Asset Pricing Model with TimeVarying Covariances. Journal of Political Economy, 96(1), 116-131. Retrieved from https://www.jstor. org/stable/1830713?seq=1\#page_ scan_tab_contents

8. Bowman, R. G., Chan, K. F., \& Comer, M. R. (2010). Diversification, rationality and the ASEAN economic crisis. PacificBasin Finance Journal, 18(1), 1-23. https://doi.org/10.1016/j.pacfin.2009.05.003

9. Cappiello, L., Engle, R., \& Sheppard, K. (2006). Asymmetric dynamics in the correlations of global equity and bond returns. Journal of Financial Econometrics, 4(4), 537-572. https:// doi.org/10.1093/jjinec/nbl005

10. Cha, B., \& Oh, S. (2000). The relationship between developed equity markets and the Pacific Basin's emerging equity markets. International Review of Economics \& Finance, 9(4), 299-322. https://doi.org/10.1016/S10590560(00)00057-5

11. Chaudhuri, K., \& Wu, Y. (2003). Random walk versus breaking trend in stock prices: Evidence from emerging markets. Journal of Banking \& Finance, 27(4), 575-592. https://doi.org/10.1016/S03784266(01)00252-7
12. Cheung, Y., \& Ng, L. (1993). Interactions between the US and Japan stock market indices. Journal of International Financial Markets, Institutions \& Money, 2(2), 51-70. Retrieved from https://www. tandfonline.com/doi/abs/10.1300/ J282V02N02_03

13. Chiang, T. C., Jeon, B. N., \& Li, H. (2007). Dynamic correlation analysis of financial contagion: Evidence from ASEAN markets. Journal of International Money and Finance, 26(7), 1206-1228. https://doi.org/10.1016/j.jimonfin.2007.06.005

14. Chittedi, K. R. (2015). Financial crisis and contagion effects to Indian stock market:'DCCGARCH'analysis. Global Business Review, 16(1), 50-60. https://doi. org/10.1177\%2F0972150914553507

15. Engle, R. (2002). Dynamic conditional correlation. Journal of Business and Economic Statistics, 20(3), 339-350. https://doi. org/10.1198/073500102288618487

16. Engle, R. F. (1982). Autoregressive Conditional Heteroscedasticity with Estimates of the Variance of United Kingdom Inflation. Econometrica, 50(4), 987-1007. https://doi. org/10.2307/1912773

17. Engle, R., \& Ng, V. (1993). Measuring and testing the impact of news on volatility. Journal of finance, 48(5), 1749-1778. https:// doi.org/10.2307/2329066 
18. Engle, R., \& Susmel, R. (1993). Common volatility in international equity markets. Journal of Business \& Economic Statistics, 11(2), 167-176. https://doi. org/10.2307/1391368

19. Groenen, P., \& Franses, P. (2000). Visualizing time-varying correlations across stock markets. Journal of Empirical Finance, 7(2), 155-172. https://doi.org/10.1016/ S0927-5398(00)00009-8

20. Hou, Y., \& Li, S. (2016). Information transmission between US and China index futures markets: An asymmetric DCC GARCH approach. Economic Modelling, 52, 884-897. https://doi.org/10.1016/j. econmod.2015.10.025

21. Johansen, S. (1991). Estimation and hypothesis testing of cointegration vectors in Gaussian vector autoregressive models. Econometrica: Journal of the Econometric Society, 59(6), 1551-1580. https://doi. org $/ 10.2307 / 2938278$

22. King, M., \& Wadhwani, S. (1990). Transmission of volatility between stock markets. Review of Financial Studies, 3(1), 5-33. Retrieved from https://www.jstor.org/ stable/2961954?seq=1\#page_scan_ tab_contents

23. King, M., Sentana, E., \& Wadhwani, S. (1994). Volatility and Links between National Stock Markets. Econometrica, 62(4), 901-933. https://doi.org/10.2307/2951737

24. Koutmos, G., \& Booth, G. (1995). Asymmetric volatility transmission in international stock markets. Journal of International Money and Finance, 14(6), 747-762. https://doi. org/10.1016/0261-5606(95)00031-3

25. Kroner, K., \& Ng, V. (1998).

Modeling asymmetric comovements of asset returns. Review of Financial Studies, 11(4), 817-844. https://doi.org/10.1093/ rfs/11.4.817

26. Liu, Y. A., \& Pan, M. S. (1997). Mean and Volatility Spillover Effects in the U.S. and Pacific-Basin Stock Markets. Multinational Finance Journal, 1(1), 47-62. https://doi. org/10.17578/1-1-3

27. Longin, F., \& Solnik, B. (1995). Is the correlation in international equity returns constant: 1960-1990? Journal of International Money and Finance, 14(1), 3-26. https://doi. org/10.1016/0261-5606(94)00001-H

28. Longin, F., \& Solnik, B. (2001). Extreme correlation of international equity markets. The Journal of Finance, 56(2), 649-676. https://doi. org/10.1111/0022-1082.00340

29. Markowitz, H. (1959). Portfolio Selection: Efficient Diversification of Investment. New York: John Wiley. http://dx.doi.org/10.2307/2326204

30. Markowitz, H. (1991a). Foundations of portfolio theory. Journal of finance, 46(2), 469-477. https://doi. org/10.2307/2328831

31. Markowitz, H. (1991b). Portfolio selection: efficient diversification of invstments: Wiley.

32. Markowitz, H., Todd, G., \& Sharpe, W. (2000). Mean-variance analysis in portfolio choice and capital markets. Wiley.

33. Mazzotta, S. (2008). How important is asymmetric covariance for the risk premium of international assets? Journal of Banking \& Finance, 32(8), 1636-1647. https://doi. org/10.1016/j.jbankfin.2007.11.017

34. Morana, C., \& Beltratti, A. (2002). The effects of the introduction of the euro on the volatility of European stock markets. Journal of banking and finance, 26(10), 2047-2064. http://dx.doi.org/10.1016/S03784266(01)00182-0

35. Morana, C., \& Beltratti, A. (2008). Comovements in international stock markets. Journal of International Financial Markets, Institutions and Money, 18(1), 31-45. https://doi. org/10.1016/j.intfin.2006.05.001

36. Osterwald-Lenum, M. (1992). A note with quantiles of the asymptotic distribution of the maximum likelihood cointegration rank test statistics. Oxford bulletin of economics and statistics, 54(3), 461-472. https:// doi.org/10.1111/j.1468-0084.1992. tb00013.x

37. Ramchand, L., \& Susmel, R. (1998). Volatility and cross correlation across major stock markets. Journal of Empirical Finance, 5(4), 397-416. https://doi.org/10.1016/S09275398(98)00003-6
38. Solnik, B., Boucrelle, C., \& Le Fur, Y. (1996). International market correlation and volatility. Financial Analysts Journal, 52(5), 17-34. Retrieved from https://www.jstor. org/stable/4479942?seq=1\#page_ scan_tab_contents

39. Syriopoulos, T. (2004). International portfolio diversification to Central European stock markets. Applied Financial Economics, 14(17), 12531268. https://doi.org/10.1080/09603 10042000280465

40. Syriopoulos, T. (2006). Risk and return implications from investing in emerging European stock markets. Journal of International Financial Markets, Institutions and Money, 16(3), 283-299. Retrieved from https://econpapers.repec.org/ article/eeeintfin/v_3a16_3ay_3a200 6_3ai_3a3_3ap_3a283-299.htm

41. Syriopoulos, T., \& Roumpis, E. (2009). Dynamic correlations and volatility effects in the Balkan equity markets. Journal of International Financial Markets, Institutions and Money, 19(4), 565-587. https://doi. org/10.1016/j.intfin.2008.08.002

42. Trabelsi, N., \& Naifar, N. (2017). Are Islamic stock indexes exposed to systemic risk? Multivariate GARCH estimation of CoVaR. Research in International Business and Finance, 42, 727-744. https://doi. org/10.1016/j.ribaf.2017.07.013

43. Yang, J., Kolari, J., \& Min, I. (2003). Stock market integration and financial crises: the case of Asia. Applied Financial Economics, 13(7), 477-486. https://doi. org/10.1080/09603100210161965

44. Yang, S., \& Doong, S. (2004). Price and volatility spillovers between stock prices and exchange rates: Empirical evidence from the G-7 countries. International Journal of Business, 3(2), 139-153. Retrieved from https://www.researchgate. net/publication/268000643_Price_ and_Volatility_Spillovers_between_Stock_Prices_and_Exchange_Rates_Empirical_Evidence_ from_the_G-7_Countries 